\title{
Web Content Analysis On Sustainable Campus Operation (SCO) Initiatives
}

\author{
Ruzaimah Razman ${ }^{1}$, Abd Halid Abdullah ${ }^{1}$, Abdul Zaki Abd Wahid ${ }^{1}$ and Rahmat Muslim ${ }^{1}$ \\ ${ }^{1}$ Faculty of Civil and Environmental Engineering, Universiti Tun Hussien Onn Malaysia
}

\begin{abstract}
The purpose of this paper is to identify and analyse the current practices implemented in global universities for achieving sustainability throughout campus operations. This study adopted a web content analysis method where 30 international green universities' websites have been thoroughly examined to identify common initiatives implemented to achieve sustainability through campus operations. The findings are ranked based on the implementation of these initiatives by participating universities. From the websites reviewed, as much as 31 initiatives have been identified as common initiatives frequently implemented by green universities to achieve sustainability in campus operations. It was found that the common initiatives frequently implemented by most of the universities include 'Provide bin with clearly marked signs to increase the number of recycling items', and 'Generate electricity on campus by establishing power generation plants' with $87 \%$ and $83 \%$ respectively. This paper fills the gap by presenting the investigation of sustainability initiatives from some of the major green universities internationally. It is suggested that higher education institutions, particularly Malaysian universities, initiate or manage their implementation of sustainable campus operation (SCO) initiatives based on the findings of this research.
\end{abstract}

\section{Introduction}

Universities are generally known for their wide area with large population, and carrying out complex operations and activities which comprise various teaching and learning, research and development, and provision of support services. They can generate significant environmental impacts because of their huge use of energy, extensive transportation, massive waste, high consumption of materials, and extensive development of built facilities [1]. Most researchers believe that to overcome these issues, elements of campus sustainability should be incorporated into all aspects of university's governance, operation, education, research, and outreach [2][3][4][7][8]. However, dimensions of governance and operations have been given more focus in assessing the sustainability at university as compared to other areas [7].

In Malaysia, although there have been many campus sustainability initiatives being implemented by local universities to achieve Sustainable Campus Operations (SCO), it seems that the efforts are still divergent and not systematically applied. The knowledge on the current and actual campus sustainability practices is still limited as there is currently very few published articles provide in depth discussion on the conceptual or practical frameworks of campus sustainability [1]. Therefore, further studies are still needed in order to share information, understand the issues and concepts, and develop action plans to be used as guidelines that are appropriate to the local universities. This paper fills the gap by presenting the investigation of the real

\footnotetext{
a Corresponding author: emmaradzman@gmail.com
}

sustainability practices from some major green universities in the world. Malaysian universities could use the findings whether to initiate or to manage their implementation of SCO-initiatives.

\section{Sustainable Campus Operations Background}

About 400 university leaders from over 52 countries have signed Talloires Declaration to show their commitment and support to environmental sustainability in Higher Education Institutions (HEIs) [9]. The declaration urges universities to carry out a more sustainable campus operations, as well as incorporating sustainability and environmental literacy within universities' approach as a whole by explicitly linking research, educational and operational activities. The universities should be the role model of environmental responsibility by establishing institutional ecology policies and practices of resource conservation, recycling, waste reduction, and environmentally sound operations [10]. Kyoto Declaration also encourages universities to review their operations to reflect the sustainable development practices. Both declarations are often referred by HEIs to develop and implement SCO through centralized programs to promote green practices in achieving campus sustainability objectives. It is not surprising that most of the university's sustainability policies and sustainability initiatives focus more on operations rather than other areas [11]. 
Campus Operations is responsible for the provision of all buildings and facilities within universities to maintain a safe, comfortable and attractive campus environment that supports excellence in teaching, learning and research. Sustainable development benefits can be achieved through consuming fewer resources in construction and operation, reduce negative impacts on environment, using efficient building material energy, minimize construction waste, and reduce planning risk, extended building life and viability [5] [6]

In adopting sustainability in campus operations, various focus areas and goals are being set by universities around the world. Based on [7], campus operation and environmental performance are related to energy and water consumption, and waste and hazardous materials management. While, [12] mentioned that Environmental Management System (EMS) covers two areas, namely (i) environmental management and improvement, which relates to waste minimization, energy efficiency, and environmental conservation, and (ii) green campus, which aims to promote construction of green buildings and transportation facilities. Sustainable operations emphasize features such as saving, environmental quality, and efficiency and effectiveness of resources for university. For instant, the operations must be able to lower the carbon emission, as well as able to reduce the consumption of non-renewable sources, and the resources are selected based on life cycle assessment.

On a personal level, by doing recycling, limit energy use, buy products with low carbon footprints, and buy products from sustainable sources are the several methods adopted to go green. In turn, universities can do their bit too, such as developing their own sustainability policies and implementing the initiatives towards SCO. As universities are unique due to its topography, population size, culture and climate where they exist, and etc., therefore the selection of areas and initiatives that can be effectively conducted at a particular university are important to be identified.

\section{Method}

A total of 30 green universities have been identified as samples for this study. Table 1 outlines the list of universities obtained through Google search using several keywords including 'Campus Sustainability Initiatives', 'Campus Green Practices', 'Members of International Alliance of Research Universities (IARU)', 'University Listed in UI GreenMetric', and 'The 39 Greenest Universities'. The investigation of the websites is only focused on web menus and content of web pages consist of the campus operations practices or initiatives adopted at the universities. From the investigation of the 30 green universities' websites, as much as 31 initiatives have been identified as common initiatives frequently implemented to achieve SCO.

\section{Findings}

Table 2 presents the findings of this study. Most of the green universities have implemented initiatives to achieve sustainability in campus operations by 'Provide bin with clearly marked signs to increase the number of recycling items' and 'Generating electricity in campus through a large-scale plants or power generation plants e.g. solar energy to reduce nonrenewable fuels'. The top 2 initiatives mentioned earlier can be considered as the most significant initiatives implemented by most of the international universities to achieve SCO with involvement percentages of $87 \%$ and $83 \%$, respectively.

Including the two initiatives mentioned above, the top 5 list of initiatives that are frequently implemented by universities towards achieving SCO also consist of 'Design, build and renovate university buildings according to green building certification/standard/index', 'Collect food waste from dining halls and convert it into a high grade compost which can be used in the gardens and landscape in the campus', 'Use of energy efficient equipment and eco-friendly products in campus to enhance performance and to reduce carbon footprint' and 'Use unprocessed water supply such as portable water, rainwater harvesting or on-site recycling of water which can be used in operational activities and reduce the water bills'. Other implemented initiatives such as 'Providing secure bicycle storage area', 'Provide parking facilities for carpooling, bicycling and shuttle bus purpose', 'Providing safe cycling \& walking paths', 'placing the bin at convenient place' and 'Buying foods from local producers to reduce the distance in transporting foods to consumer' are also among the significant initiatives frequently implemented on campus encompassing 60$80 \%$ of universities considered in this study.

However, several others; such as 'Create native and drought plants landscape as significantly reduced the need for irrigation and maintenance', 'Provide in-campus workshop to maintain and repair bicycles', 'Collect and process garden/landscape waste into compost for a campus gardening and landscape', 'Consider the full lifecycle of building from the extraction of resources during building construction, maintenance, demolition and material recycling during renovation' and 'Provide real time shuttle-bus schedules', are less adopted as only less than $40 \%$ of the green universities implemented such initiatives. Whereas, the only initiative that can be considered as insignificant is 'providing showers for cyclist' since it is rarely implemented by the green universities towards achieving SCO. 
Table 1. Samples of Green Universities

\begin{tabular}{|c|c|c|c|c|c|}
\hline \multirow[t]{2}{*}{ Green Universities Identified } & \multicolumn{5}{|c|}{ Search Key words } \\
\hline & $\begin{array}{l}\text { Campus } \\
\text { Sustainability } \\
\text { Initiatives }\end{array}$ & $\begin{array}{l}\text { Campus } \\
\text { Green } \\
\text { Practices }\end{array}$ & $\begin{array}{l}\text { Members of } \\
\text { International } \\
\text { Alliance of } \\
\text { Research } \\
\text { Universities } \\
\text { (IARU) }\end{array}$ & $\begin{array}{l}\text { Top } 15 \\
\text { University } \\
\text { Listed in UI } \\
\text { Green Metric } \\
2015\end{array}$ & $\begin{array}{l}\text { The } 39 \\
\text { Greenest } \\
\text { Universities } \\
\text { of } 2015\end{array}$ \\
\hline University of Nottingham [13] & $\mathrm{X}$ & & & $\mathrm{X}$ & \\
\hline University College Cork [14] & $\mathrm{X}$ & & & $\mathrm{X}$ & \\
\hline University of California, Davis [15] & $\mathrm{X}$ & & & $\mathrm{X}$ & \\
\hline University of Oxford [16] & $\mathrm{X}$ & & $\mathrm{X}$ & $\mathrm{X}$ & \\
\hline University of Connecticut [17] & $\mathrm{X}$ & & & $\mathrm{X}$ & \\
\hline Colorado State University [18] & $X$ & & & & $\mathrm{X}$ \\
\hline Harvard University [19] & $\mathrm{X}$ & & & & \\
\hline Duke University [20] & $\mathrm{X}$ & & & & \\
\hline Thompson Rivers University [21] & $\mathrm{X}$ & & & & \\
\hline Bloomsburg University [22] & $\mathrm{X}$ & & & & \\
\hline Emory University [23] & $\mathrm{X}$ & & & & $\mathrm{X}$ \\
\hline Colgate University [24] & $\mathrm{X}$ & & & & $\mathrm{X}$ \\
\hline University of California, Berkeley [25] & $\mathrm{X}$ & & $\mathrm{X}$ & $\mathrm{X}$ & \\
\hline Cornell University [26] & $\mathrm{X}$ & & & & $\mathrm{X}$ \\
\hline University of Alberta [27] & $\mathrm{X}$ & & & & \\
\hline Gonzaga University [28] & $\mathrm{X}$ & & & & \\
\hline University of Massachusetts Amherst [29] & $\mathrm{X}$ & $X$ & & & $\mathrm{X}$ \\
\hline Lewis and Clark Institute [30] & & $\mathrm{X}$ & & & \\
\hline University of California, Irvine [31] & & $\mathrm{X}$ & & & \\
\hline Carnegie Mellon University [32] & & $\mathrm{X}$ & & & \\
\hline Australian National University [33] & & & $\mathrm{X}$ & & \\
\hline National University of Singapore [34] & & & $\mathrm{X}$ & & \\
\hline University of Cambridge [35] & & & $\mathrm{X}$ & & \\
\hline University of Cape Town [36] & & & $\mathrm{X}$ & & \\
\hline University of Copenhagen [37] & & & $\mathrm{X}$ & & \\
\hline Yale University [38] & & & $\mathrm{X}$ & & \\
\hline Northeastern University [39] & & & & $\mathrm{X}$ & \\
\hline University of Limerick [40] & & & & $\mathrm{X}$ & \\
\hline University of North Carolina [41] & & & & $X$ & $\mathrm{X}$ \\
\hline University of Plymouth [42] & & & & $\mathrm{X}$ & \\
\hline
\end{tabular}

Table 2. Ranking of SCO Initiatives

\begin{tabular}{|c|c|c|c|c|}
\hline \multirow{2}{*}{\multicolumn{2}{|c|}{ SCO-initiatives }} & \multicolumn{3}{|c|}{30 green universities websites } \\
\hline & & Frequency & Percentage & Average \\
\hline \multicolumn{5}{|c|}{ 1) Energy } \\
\hline E1 & $\begin{array}{l}\text { Generate electricity on campus by establishing large-scale plants or } \\
\text { power generation plants such as solar energy systems to } \\
\text { reduce/replace total consumption of nonrenewable fuels (e.g.: oil \& } \\
\text { natural gas) }\end{array}$ & 25 & $83 \%$ & \multirow[t]{2}{*}{$76.5 \%$} \\
\hline E2 & $\begin{array}{l}\text { Use of energy efficient equipment and eco-friendly products within } \\
\text { the campus to enhance performance and reduce carbon footprint }\end{array}$ & 21 & $70 \%$ & \\
\hline \multicolumn{5}{|c|}{ 2) Building } \\
\hline B3 & $\begin{array}{l}\text { Install building management systems to monitor real-time electricity, } \\
\text { water and chilled-water usage }\end{array}$ & 14 & $47 \%$ & \multirow{4}{*}{$52 \%$} \\
\hline B4 & $\begin{array}{l}\text { Consider the full life-cycle of building from extraction of resources } \\
\text { to demolition and recycling when building or renovating a building }\end{array}$ & 11 & $37 \%$ & \\
\hline B5 & $\begin{array}{l}\text { Design, build, and renovate building according to green certification } \\
\text { standard }\end{array}$ & 23 & $77 \%$ & \\
\hline B6 & Design the building for high performance & 14 & $47 \%$ & \\
\hline
\end{tabular}




\begin{tabular}{|c|c|c|c|c|}
\hline \multirow{2}{*}{ G) } & \multicolumn{3}{|l|}{ Green space } & \multirow{4}{*}{$49 \%$} \\
\hline & $\begin{array}{l}\text { Reserve green area to reduce heat-island effect by provide effective } \\
\text { shading, oxygen, and isolating carbon emissions generated by } \\
\text { campus activities }\end{array}$ & 17 & $57 \%$ & \\
\hline G8 & $\begin{array}{l}\text { Create green area for storm water management to reduce the risk of } \\
\text { flooding }\end{array}$ & 15 & $50 \%$ & \\
\hline G9 & $\begin{array}{l}\text { Create native and drought plants landscape as significantly reduced } \\
\text { the need for irrigation and maintenance }\end{array}$ & 12 & $40 \%$ & \\
\hline \multicolumn{5}{|c|}{ 4) Water } \\
\hline Wr10 & $\begin{array}{l}\text { Use of water efficient equipment which have water conservation and } \\
\text { water saving features }\end{array}$ & 17 & $57 \%$ & \multirow[b]{2}{*}{$63.5 \%$} \\
\hline Wr11 & $\begin{array}{l}\text { Use unprocessed water supply such as portable water, rainwater } \\
\text { harvesting or on-site recycling of water which can be used in } \\
\text { operational activities }\end{array}$ & 21 & $70 \%$ & \\
\hline \multicolumn{5}{|c|}{ 5) Purchasing \& procurement } \\
\hline P12 & $\begin{array}{l}\text { Establish central information medium or a portal to assembled } \\
\text { materials for re-use or exchange }\end{array}$ & 18 & $60 \%$ & \multirow{4}{*}{$55 \%$} \\
\hline P13 & $\begin{array}{l}\text { Run programs for students or department to donate or sale unwanted } \\
\text { items to local community and charities }\end{array}$ & 13 & $43 \%$ & \\
\hline P14 & $\begin{array}{l}\text { Set technical specifications or purchasing guidelines with include } \\
\text { environmental preferable criteria }\end{array}$ & 18 & $60 \%$ & \\
\hline P15 & $\begin{array}{l}\text { Include procedures of treatment or proper handling of solid waste } \\
\text { (inorganic waste), hazardous waste and sewage disposal, without } \\
\text { polluting the environment and public health }\end{array}$ & 17 & $57 \%$ & \\
\hline \multicolumn{5}{|c|}{ 6) Transport } \\
\hline T16 & $\begin{array}{l}\text { Use renewable fuels such as bio-diesel or use of energy efficient } \\
\text { vehicles such as hybrid or electric vehicle for university } \\
\text { transportation (official vehicle or even bus) }\end{array}$ & 17 & $57 \%$ & \multirow{9}{*}{$49.9 \%$} \\
\hline T17 & Offer staff and students to purchase public transport season tickets & 18 & $60 \%$ & \\
\hline T18 & Provide real time shuttle-bus schedules & 10 & $33 \%$ & \\
\hline T19 & $\begin{array}{l}\text { Provide a centralized parking facilities for carpooling, bicycling, } \\
\text { walking, and shuttle bus purpose }\end{array}$ & 19 & $63 \%$ & \\
\hline T20 & Provide secure bicycle storage area & 20 & $67 \%$ & \\
\hline T21 & Provide showers for cyclist & 4 & $13 \%$ & \\
\hline T22 & Offer access to free or cheap bicycles or provide bicycle charter & 16 & $53 \%$ & \\
\hline T23 & Provide safe cycling $\&$ walking paths & 19 & $63 \%$ & \\
\hline T24 & Provide in-campus workshop to maintain and repair bicycles & 12 & $40 \%$ & \\
\hline \multicolumn{5}{|c|}{ 7) Waste } \\
\hline Ws25 & $\begin{array}{l}\text { Re-use or recycle construction and demolition waste (e.g.: unused } \\
\text { metal, concrete, plywood etc.) in different project applications }\end{array}$ & 13 & $43 \%$ & \multirow{5}{*}{$61.2 \%$} \\
\hline Ws26 & $\begin{array}{l}\text { Provide bin with clearly marked signs to increase the number of } \\
\text { recycling items }\end{array}$ & 26 & $87 \%$ & \\
\hline Ws27 & $\begin{array}{l}\text { Place the bin in areas both convenient and close to the waste source } \\
\text { and allow easy access by the community members }\end{array}$ & 19 & $63 \%$ & \\
\hline Ws28 & $\begin{array}{l}\text { Collect and turned garden/landscaping waste into compost for re- } \\
\text { used on campus gardens and landscape }\end{array}$ & 12 & $40 \%$ & \\
\hline Ws29 & $\begin{array}{l}\text { Collect food waste from dining halls and convert it into a high grade } \\
\text { compost which can be used in the gardens and landscape in the } \\
\text { campus }\end{array}$ & 22 & $73 \%$ & \\
\hline \multicolumn{5}{|c|}{ 8) Food } \\
\hline F30 & $\begin{array}{l}\text { Buying foods from local producers to reduce the distance that food is } \\
\text { transported from product consumer }\end{array}$ & 19 & $63 \%$ & \multirow{2}{*}{$61.5 \%$} \\
\hline F31 & $\begin{array}{l}\text { Choose the agricultural products that using organic fertilizer or } \\
\text { minimal chemical fertilizer }\end{array}$ & 18 & $60 \%$ & \\
\hline
\end{tabular}

However, based on the average score of each element of SCO initiatives, it can be seen clearly from Table 2 that the Energy sector contributes the most initiatives implemented amongst the green universities with $76.5 \%$ followed by Water $63.5 \%$, Foods $61.5 \%$ and Waste $61.2 \%$. Meanwhile, element of Purchasing and Procurement has received less attention with only $55 \%$ of the initiatives implemented by the green universities as well as other elements of SCO initiatives including
Building area $52 \%$, Transport $49.9 \%$, and Green space $49 \%$, respectively.

\section{Conclusions and Recommendation}

The concept of sustainable campus is relatively new in Malaysian, and several local public universities are still at the infant stage in adopting and implementing the SCO initiatives towards sustainability. Obviously, the planning and implementation of these initiatives should be phased 
and prioritized accordingly so that they can affect optimally on sustainability in campus operations.

There are various initiatives and sustainable practices that can be adopted and implemented by the top management to ensure that universities operate in a sustainable manner. However, more focus and attention should be given to the initiatives that can give positive impact on the environment, economic and social aspects of the campus community. In the early stages, the local universities may implement only the top 5 lists (e.g. Provide bin with clearly marked, Generating electricity in campus through power generation plants, Design, build and renovate building according to green building certification/standard/index, Compost foods wastes, and Use of energy efficient equipment and eco-friendly products) to ensure more focused and manageable implementation of the initiatives for successful results. Otherwise, top management can also implement sustainability initiatives according to the focus areas such as energy and water sectors, as this focus area can give greater impact on sustainable development at the university although it requires higher initial investment for a long term benefits.

However, it is not denying that factors such as self-awareness, knowledge, finance, leadership, organization, technology, climate, and etc. also affect the selection of sustainability initiatives to be implemented. The initiatives discussed earlier are for reference purposes only and unnecessarily be implemented fully by local universities. Finally, the SCO initiatives identified from website review will be considered for further investigation on their level of significance through questionnaire survey should they be implemented at Malaysian universities.

\section{Acknowledgements}

This paper is a part of the research work funded by the Ministry of Higher Education Malaysian under Short Term Grant Scheme (Vote U345). We are also grateful to those individuals who have rendered their assistance throughout this study.

\section{References}

1. Gunawan, Tarigan, E., Prayogo, D.N., and Mardiono, L. (2012). "Eco-sustainable Campus Initiatives: A Web Content Analysis," Proceedings of The 3rd International Conference on Technology and Operations Management: Sustaining Competitiveness through Green Technology Management, Bandung-Indonesia (July 4-6), pp. 59-65. ISBN: 978-979-15458-4-6.

2. Cortese AD. (2003) "The critical role of higher education in creating a sustainable future", Planning for Higher Education, vol 31, no 3, pp. $15-22$

3. Velazquez, L., Munguia, N.P.A. and Taddei, J. (2004), "A Sustainable University: What can be the matter?" Journal of Cleaner Production, vol. 14 , iss.9-11, pp. $810-819$
4. Waas, T. et al (2012), "Sustainable Higher Education: Understanding and Moving Forward", Retrieved on August 6, 2015 from https://lirias.kuleuven.be/handle/123456789/374 $\underline{087}$.

5. Azis A.A.A.et al (2012), "Challenges faced By Construction Industry in Accomplishing Sustainability Goals", IEEE Symposium on Business, Engineering and Industrial Applications, pp. 630-634. ISBN: 978-1-45771632-4.

6. Yunus R. \& Jay Y. (2011), "Sustainability Criteria for Industrialised Building Systems (IBS) in Malaysia", The Twelfth East AsiaPacific Conference on Structural Engineering and Construction, Procedia Engineering 14 (2011) 1590-1598.

7. Yarime \& Tanaka (2012), "The Issues and Methodologies in Sustainability Assessment Tools for Higher Education Institutions: A Review of Recent Trends and Future Challenges", Journal of Education for Sustainable Education, Vol 6(1): 63-77.

8. Norhayati, N. (2014), "Kajian Terhadap Model Kampus Lestari Universiti Awam di Malaysia: Suatu Pendekatan Terintegratif', Doctoral Thesis

9. University Leaders for a Sustainable Future, Talloires Declaration, Washington, DC. (2010), in Benjamin O. (2011), "Investigating

Sustainability Professors' Conceptualizations of Sustainability and Sustainable Universities at Dalhousie University", Retrived on January 7, 2016 from

http://www.dal.ca/content/dam/dalhousie/pdf/sci ence/environmental-scienceprogram/Honours\%20Theses/BenOjoleck.pdf

10. University Leaders for a Sustainable Future, (2001), "The Talloires Declaration", Retrived on January 7, 2016 from http://www.ulsf.org/programs talloires td.html

11. Wright, T.S.A. (2002) "Definitions and Frameworks for the Environment Sustainability in Higher Education". Higher Eduction Policy, vol 15, no 2, pp.105-20.

12. Alshuwaikhat, H.M. and Abubakar, I. (2008) "An integrated approach to achieving campus sustainability: assessment of the current campus environmental management practices", Journal of Cleaner Production, vol. 16, pp. 1777-1785.

13. Nottingham Trent University, Retrieved on September 20, 2015 from https://www.ntu.ac.uk/sustainability/ecocampus/ index.html

14. University College Cork, Retrieved on August 8, 2015 from https://www.ucc.ie/en/greencampus/

15. University of California, Davis Retrieved on October 18, 2015 from http://sustainability.ucdavis.edu/action/index.ht $\underline{\mathrm{ml}}$ 
16. University of Oxford, Retrieved on August 8, 2015 from http://www.sustainia.me/solutions/

17. University of Connecticut, Retrieved on October 20, 2015 from

http://ecohusky.uconn.edu/development/tour.ht $\underline{\mathrm{ml}}$

18. Colorado State University Retrieved on August 13, 2015 from

https://www.fm.colostate.edu/sustain/index.cfm? page $=$ projects/energy

19. Harvard University, Retrieved on October 13, 2015 from http://green.harvard.edu

20. Duke University Retrieved on August 13, 2015 from http://sustainability.duke.edu/campus_initiatives /index.html

21. Thompson Rivers University Retrieved on August 13, 2015 from http://www.tru.ca/sustain/initiatives.html

22. Bloomsburg University Retrieved on August 15, 2015 from http://www.bloomu.edu/sustainability

23. Emory University Retrieved on August 15, 2015 from http://sustainability.emory.edu

24. Colgate University Retrieved on August 15, 2015 from http://www.colgate.edu/distinctlycolgate/sustainability/climate-actionplanning/alternative-transportation

25. University of California, Berkeley Retrieved on September 10, 2015 from http://sustainability.berkeley.edu

26. Cornell University (2013), "Sustainability: Today and Tomorrow", Retrieved on August 07, 2015 from

http://cscproduction.s3.amazonaws.com/2014/04 /06/21/20/07/271/PSCC2013Sustainability Tod ay Tomorrow FINAL.pdf.

27. University of Alberta Retrieved on August 18, 2015 from http://www.sustainability.ualberta.ca/en/Campus Initiatives.aspx

28. Gonzaga University Retrieved on August 18, 2015 from http://www.gonzaga.edu/campusresources/sustainability/initiatives.asp

29. University of Massachusetts Amherst Retrieved on August 18, 2015 from https://www.umass.edu/sustainability/greencampus

30. Lewis and Clark Institute Retrieved on August 18,2015 from https://www.lclark.edu/about/sustainability/cam pus/

31. University of California, Irvine Retrieved on August 19, 2015 from

http://sustainability.uci.edu/sustainablecampus/

32. Carnegie Mellon University Retrieved on August 19, 2015 from http://www.cmu.edu/environment/recyclingwaste/index.html

33. Australian National University Retrieved on August 25, 2015 from

http://sustainability.anu.edu.au/themes/energyand-climate

34. National University of Singapore Retrieved on August 25, 2015 from http://www.nus.edu.sg/oes/

35. University of Cambridge Retrieved on August 25,2015 from http://www.environment.admin.cam.ac.uk

36. University of Cape Town Retrieved on August 26, 2015 from http://www.greening.uct.ac.za/action/

37. University of Copenhagen Retrieved on September 3, 2015 from http://greencampus.ku.dk/sustainable_campus_d evelopment/sustainability initiatives/

38. Yale University Retrieved on September 3, 2015 from http://sustainability.yale.edu

39. Northeasten University Retrieved on August 8, 2015 from http://www.northeastern.edu/sustainability/

40. University of Limerick Retrieved on September 5,2015 from http://www3.ul.ie/envirocom/Green-Guide/

41. University of North Carolina, Chapel Hill Retrieved on September 5, 2015 from http://sustainability.unc.edu/initiatives/

42. University of Plymouth Retrieved on September 5, 2015 from https://www.plymouth.ac.uk/youruniversity/sustainability/our-sustainable-campus 